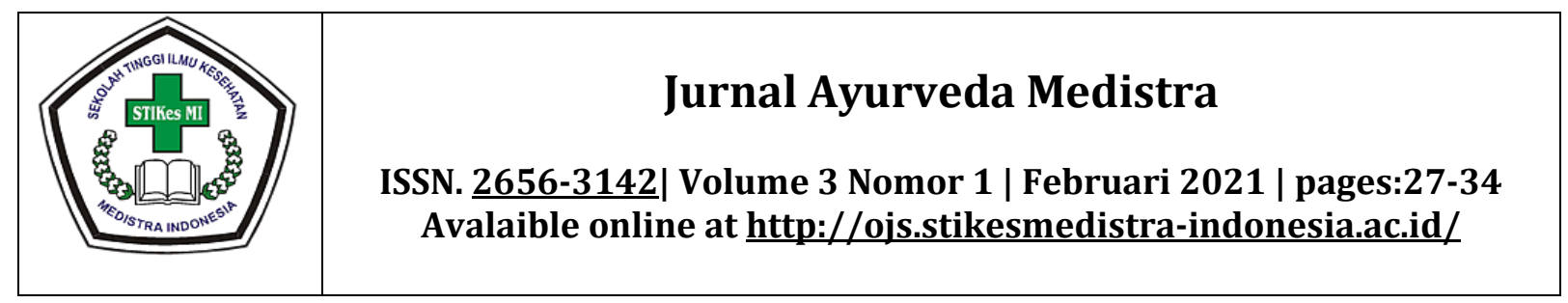

\title{
PERBANDINGAN AKTIVITAS ANTIOKSIDAN DAN TOKSISITAS ANTARA DAGING BUAH, KULIT BAGIAN DALAM DAN KULIT BAGIAN LUAR BUAH MANGGIS (GARCINIA MANGOSTANA L.)
}

\author{
Dharma Yanti \\ Program Studi Farmasi (S1) STIKes Medistra Indonesia, medistra@stikesmi.ac.id, 085709252433
}

\begin{abstract}
Abstrak
Berdasarkan percobaan terdahulu kulit buah manggis (Garcinia mangostana L.) diketahui mengandung senyawa xanthone yang memiliki aktivitas sebagai antioksidan, antitumor, antiinflamasi, antialergi, antibakteri, antijamur, antimalaria dan antikanker. Percobaan ini bertujuan untuk membandingkan aktivitas antioksidan dan toksisitas antara daging buah, kulit bagian dalam dan kulit bagian luar buah manggis.Pengujian aktivitas antioksidan dilakukan dengan metode peredaman radikal bebas DPPH (2,2-Diphenyl-1-Picrylhydrazy). Pengujian toksisitasnya dilakukan dengan metode Brine Shrimp Lethality Test (BSLT) menggunakan larva udang Artemia salina L. Berdasarkan pengujian aktivitas antioksidan yang telah dilakukan disimpulkan ketiga sampel memiliki potensi aktivitas antioksidan dengan nilai IC 50 berturut- turut, $1,95 \mu \mathrm{g} / \mathrm{ml}$ ( ekstrak kulit bagian luar) ; 7,00 $\mu \mathrm{g} / \mathrm{ml}$ (ekstrak kulit bagian dalam ); $51,10 \mu \mathrm{g} / \mathrm{ml}$ (ekstrak daging buah manggis) . Berdasarkan hasil uji toksisitas diperoleh nilai $\mathrm{LC}_{50}$ sampel berturut-turut sebesar $6,29 \mu \mathrm{g} / \mathrm{ml}$

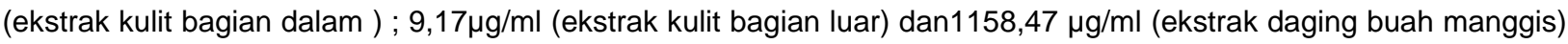
sehingga dapat disimpulkan bahwa bagian yang toksik itu adalah bagian kulit luar dan dalam sedangkan buah manggis tidak toksik.
\end{abstract}

Kata kunci: Buah Manggis (Garcinia mangostana L.), Uji Antioksidan, Uji Toksisitas.

\begin{abstract}
Based on previous experiments, Mangosteen (Garcinia mangostana L.) rind contains xanthones which have antioxidant, anti-tumor, anti-inflammatory, anti-allergenic, antibacterial, anti-fungal, anti-malarial and anti-cancer activities. This experiment aims to compare the antioxidant activity and toxicity between the pulp, inner skin and outer skin of the mangosteen fruit. Antioxidant activity testing was carried out using the DPPH (2,2-Diphenyl-1-Picrylhydrazy) free radical reduction method. The toxicity test was carried out by the Brine Shrimp Lethality Test (BSLT) method using Artemia salina $L$. shrimp larvae. Based on the antioxidant activity testing, it was concluded that the three samples had the potential for antioxidant activity with $\mathrm{IC}_{50}$ values respectively, $1.95 \mu \mathrm{g} / \mathrm{ml}$ (outer shell extract); $7.00 \mu \mathrm{g} / \mathrm{ml}$ (inner skin extract); $51.10 \mu \mathrm{g} / \mathrm{ml}$ (mangosteen pulp extract). Based on the results of the toxicity test, the LC 50 values of the samples were respectively $6.29 \mu \mathrm{g} / \mathrm{ml}$ (inner shell extract); $9.17 \mu \mathrm{g} / \mathrm{ml}$ (outer skin extract) and $1158.47 \mu \mathrm{g} / \mathrm{ml}$ (mangosteen pulp extract), so it can be concluded that the toxic parts are the outer and inner skin parts while the mangosteen fruit is not toxic.
\end{abstract}

Keywords: Mangosteen (Garcinia mangostana L.), Antioxidant test, Toxicity test 


\section{PENDAHULUAN}

Di beberapa negara di Asia Tenggara buah manggis telah digunakan sebagai obat tradisional untuk mengobati penyakit diare, disentri, radang dan sariawan [1]. Masyarakat Indonesia menggunakan buah manggis untuk mengobati penyakit diabetes hingga kanker dengan meminum air rebusan kulit buah manggis bagian dalam [2]. Berdasarkan penelitian yang telah dilakukan kulit buah manggis diketahui mengandung senyawa xanthone dengan lebih 50 macam turunannya yang telah berhasil diisolasi. Kandungan senyawa tersebut memiliki aktivitas sebagai antioksidan, antitumor,antiinflamasi, antialergi, antibakteri, antijamur, antimalaria dan antikanker [3].

Xanton, antosianin dan senyawa polyphenolic, merupakan senyawa aktif yang menyebabkan adanya aktivitas antioksidan dalam buah manggis disinyalir dapat menangkal senyawa radikal bebas penyebab kerusakan sel atau jaringan, penyakit degeneratif, hingga kanker[3]. Tanaman yang mengandung senyawa bioaktif pada prinsipnya bersifat toksik pada dosis yang tinggi. Aktivitas senyawa bioaktif pada bahan alam dapat dimonitor dengan uji bioassay yang sederhana menggunakan hewan uji seperti larva udang [4]. Pengujian toksisitas pendahuluan ini diperlukan untuk mengetahui daya toksik suatu senyawa bioaktif pada bahan alam. Daya toksik yang tinggi pada suatu bahan alam yang diperoleh dari suatu uji bioassay pendahuluan menggunakan larva udang dapat dijadikan dasar untuk pengembangannya menjadi bahan obat antikanker.

Percobaan-percobaan terdahulu mengenai buah manggis lebih banyak terfokus pada bagian kulit buahnya saja, namun belum ada yang menguji dan membandingkan aktivitas bagian buahnya. Pada percobaan kali ini dilakukan pengujian aktivitas antioksidan dan uji toksisitasnya terhadap beberapa bagian buah manggis, yaitu bagian daging buah, kulit bagian dalam dan kulit bagian luar buah manggis (Garcinia mangostana L.).
Percobaan ini bertujuan untuk membandingkan aktivitas antioksidan dan toksisitas antara daging buah, kulit bagian dalam, dan kulit bagian luar manggis (Garcinia mangostana L.). Hal ini dimaksudkan untuk mengetahui aktivitas antioksidan dan toksisitas terbesar antara ketiga bagian buah manggis tersebut sehingga dapat dijadikan dasar untuk pengujian lebih lanjut mengenai aktivitas dan pengembangannya sebagai bahan obat.

\section{METODE PENELITIAN}

Penelitian yang dilakukan terdiri dari tahap preparasi sampel dan tahap pengolahan data. Tahap preparasi sampel meliputi pembuatan simplisia kering dan ekstraksi sampel sehingga diperoleh ekstrak pekat. Tahap analisis sampel meliputi uji aktivitas antioksidan secara peredaman radikal bebas DPPH (2,2-Diphenyl1-Picrylhydrazyl) dan uji toksisitas dengan metode Brine Shrimp Lethality Test (BSLT) menggunakan larva udang Artemia salina $L$.

\section{CARA KERJA :}

\section{Preparasi Sampel :}

1.Pembuatan Simplisia Kering

Sebanyak $\pm 1,5 \mathrm{~kg}$ buah manggis yang diperoleh dari pasar tradisional dibersihkan lalu dikupas dan dibuang kelopak daun dan bekas kepala putiknya. Bagian daging buah, kulit bagian dalam yang lunak, kulit bagian luar yang keras di pisahkan. Setelah itu masing-masing bagian buah tersebut dipotong tipis-tipis lalu dikeringanginkan (di jemur diatas atap LIPI Cibinong divisi Kimia Bahan Alam) selama satu minggu.Dalam penelitian ini kadar air sampel kering tidak di tetapkan.

\section{Ekstraksi Sampel}

Simplisia kering ditimbang sebanyak 100 gram untuk kulit bagian dalam dan 50 gram untuk kulit bagian luar dan buah, lalu dimasukkan ke labu alas bulat. Ditambahkan etanol teknis sebanyak $700 \mathrm{ml}$, direfluks pada suhu $\pm 80^{\circ} \mathrm{C}$ selama 3 jam, hasil ekstraksi disaring filtratnya ditampung dalam botol kaca. Proses ekstraksi dilakukan sebanyak 3 kali untuk masing masing sampel. Filtrat yang dikumpulkan botol kaca di keringkan dengan menggunakan rotary evaporator dan penangas air. 
Analisis Sampel

\section{Uji Aktivitas Antioksidan secara Peredaman Radikal Bebas DPPH (2,2-Diphenyl-1- Picrylhydrazy!)}

Uji aktivitas antioksidan dilakukan pada tiap sampel ekstrak dengan varian kadar $(5,10,25,50$ dan 100$) \mu \mathrm{g} / \mathrm{ml}$. Ekstrak dari tiap sampel buah manggis ditimbang $50 \mathrm{mg}$ dengan teliti. Setelah itu dilarutkan dalam $10 \mathrm{ml}$ etanol Pro analisis lalu dikocok sampai homogen dengan bantuan alat sonikator, menjadi larutan yang memiliki kadar $500 \mu \mathrm{g} / \mathrm{ml}$. Sebanyak $(50,100,250,500$ dan 1000) $\mu \mathrm{L}$ larutan induk di pipet menggunakan mikropipet lalu di masukkan ke tabung reaksi berskala. Masingmasing larutan tersebut ditambahkan $1 \mathrm{ml}$ larutan DPPH 0,4058 mM. Lalu ditambahkan dengan metanol Pro analysis sampai tanda skala $5 \mathrm{ml}$, kemudian dihomogenkan dengan homogenizer. Larutan blangko dibuat tanpa penambahan ekstrak. Mulut dan badan tabung di tutup dengan aluminium foil. Perlakuan yang sama juga di lakukan pada larutan vitamin C sebagai kontrol positif. Sebanyak $3 \mathrm{mg}$ serbuk vitamin $\mathrm{C}$ ditimbang teliti, dimasukan ke labu takar $10 \mathrm{ml}$ lalu dilarutkan dengan etanol pro analisis sehingga tanda tera sehingga diperoleh larutan induk $300 \mu \mathrm{g} / \mathrm{ml}$, setelah itu larutan dikocok sehingga homogen dan dipindahkan ke botol gelap. Larutan induk di pipet sebanyak $(50,100,150,200$, dan 250) $\mu \mathrm{L}$, dimasukan ke tabung reaksi berskala. Masing masing larutan ditambahkan 1,0 mllarutan DPPH 0,4058 mM dan ditambah etanol P.A sampai $5 \mathrm{ml}$, sehingga di peroleh kadar berturut turut $(3,6,9,12,15) \mu \mathrm{g} / \mathrm{mL}$ dan dihomogenkan dengan sonikator. Mulut dan badan tabung di tutup dengan Aluminium foil. Setelah itu larutan uji dan kontrol positip diinkubasi pada suhu 37 ${ }^{\circ} \mathrm{C}$ selama 30 menit. Serapan Peredaman Radikal Bebas DPPH diukur pada panjang gelombang $517 \quad \mathrm{~nm}$ menggunakan spektrofotometer sinar tampak kemudian data dicatat.[5]

Nilai serapan yang diperoleh digunakan untuk persen inhibisi dan $\mathrm{IC}_{50}$.Persentase penghambatan (persen inhibisi) dihitung dengan rumus :

$\%$ inhibisi $=\frac{\text { Abs blangko-abs sampel }}{\text { Abs blangko }} \times 100 \%$
Data persen inhibisi yang diperoleh dihubungkan dengan konsentrasi sampel pada suatu grafik sehingga diperoleh persamaan regresi linier $(\mathrm{y}=\mathrm{ax}+\mathrm{b})$. Nilai $\mathrm{IC}_{50}$ (Inhibition Concentration 50) atau konsentrasi suatu zat antioksidan yang mampu menghambat $50 \%$ radikal bebas dihitung dengan memasukkan y $=50$ pada regresi linier tersebut dan nilai $\mathrm{x}$ sebagai nilai $\mathrm{IC}_{50}$. Ekstrak dinyatakan memiliki aktivitas antioksidan jika nilai $\mathrm{IC}_{50}<150 \mu \mathrm{g} / \mathrm{ml}$. Antioksidan dikatakan sangat kuat jika memiliki $\mathrm{IC}_{50}$ kurang dari $50 \mathrm{ppm}$, antioksidan kuat memiliki nilai $\mathrm{IC}_{50}$ berada pada kisaran 50 ppm sampai 100 ppm, antioksidan sedang memiliki nilai IC $\quad 50100$ ppm sampai 150 ppm, antioksidan lemah memiliki nilai IC 50 di atas 150 ppm sampai 200 ppm.

\section{Uji Toksisitas secara Brine Shrimp Lethality Test (BSLT).}

Masing-masing ekstrak dibuat larutan induknya dengan konsentrasi $2000 \mu \mathrm{g} / \mathrm{ml}$ dengan cara menimbang ekstrak sebanyak 40 mg di masukan ke botol vial, lalu di tambahkan DMSO 99\% sebanyak 10 tetes, dikocok sehingga larut. Lalu di tambahkan air laut sehingga volume akhir $20 \mathrm{ml}$. Kadar larutan stok tersebut $2000 \mu \mathrm{g} / \mathrm{ml}$. Dari larutan tersebut dibuat larutan $20 \mu \mathrm{g} / \mathrm{ml}, 200 \mu \mathrm{g} / \mathrm{ml}$ sebanyak 20 $\mathrm{ml}$. Larutan uji $(1000,100,10 \mu \mathrm{g} / \mathrm{ml})$ dibuat dengan memipet $5 \mathrm{ml}$ larutan induk $(2000,200$, $20 \mu \mathrm{g} / \mathrm{ml}$ ) lalu dimasukan ke botol vial dan ditambahkan air laut sampai 10 ml,homogenkan. Masing masing larutan uji ditambahkan 10 ekor larva udang Artemia salina $L$. yang berumur 48 jam (nauplii). Setiap konsentrasi dibuat $3 \times$ pengulangan (triplo). Sebagai kontrol digunakan air laut yang berisi 10 ekor udang tanpa ekstrak. Botol uji di simpan dibawah lampu neon selama 24 jam. Pengamatan dilakukan dengan menghitung jumlah larva udang yang mati kemudian dicatat.

Data yang diperoleh diolah dengan metode probit analisis secara komputerisasi menggunakan SPSS 14 untuk menentukan nilai LC $_{50}$ (Lethal Concentration 50) yaitu dosis tunggal suatu zat yang secara statistik dapat membunuh $50 \%$ hewan uji. Suatu ekstrak dikatakan toksik jika $\mathrm{LC}_{50}<1000 \mu \mathrm{g} / \mathrm{ml}$.

\section{Metode Pengolahan Data}


Tahap pengolahan data dilakukan dengan mengolah data hasil pengujian aktivitas antioksidan secara statistik menggunakan regresi linier untuk menentukan nilai $\mathrm{IC}_{50}$ / Inhibiting Concentration 50 (konsentrasi suatu antioksidan yang mampu menghambat $50 \%$ aktivitas radikal bebas) sedangkan data hasil uji toksisitas diolah secara komputerisasi dengan probit analysis method menggunakan software SPSS 14 untuk menentukan nilai LC $_{50} /$ Lethal Concentration 50 (dosis tunggal suatu zat yang dapat membunuh $50 \%$ hewan uji).

\section{HASIL DAN PEMBAHASAN}

Tabel 1. Data Hasil Ekstraksi Sampel Buah Manggis

\begin{tabular}{|l|l|l|l|l|l|}
\hline $\begin{array}{l}\text { N } \\
\text { O }\end{array}$ & $\begin{array}{l}\text { Samp } \\
\text { el }\end{array}$ & $\begin{array}{l}\text { Bobot } \\
\text { Simplisi } \\
\text { a } \\
\text { Kering } \\
(\mathrm{g})\end{array}$ & $\begin{array}{l}\text { Bobot } \\
\text { Yang } \\
\mathrm{Di} \\
\text { Ekstra } \\
\mathrm{k}(\mathrm{g})\end{array}$ & $\begin{array}{l}\text { Bobot } \\
\text { Ekstra } \\
\mathrm{k}(\mathrm{g})\end{array}$ & $\begin{array}{l}\text { Persen } \\
\text { Rendem } \\
\text { en (\%) }\end{array}$ \\
\hline 1 & $\begin{array}{l}\text { Dagin } \\
\mathrm{g}\end{array}$ & 65 & 50 & 27,53 & 55,06 \\
\hline Buah & $\begin{array}{l}\text { Kulit } \\
\text { Bagia } \\
\mathrm{n} \\
\text { Dalam }\end{array}$ & 265 & 100 & 43,86 & 43,86 \\
\hline 3 & $\begin{array}{l}\text { Kulit } \\
\text { Bagia } \\
\text { n Luar }\end{array}$ & 90 & 50 & 6,94 & 13,88 \\
\hline
\end{tabular}

Berdasarkan Tabel 1. Diketahui ekstrak terbanyak di peroleh dari daging buah manggis dengan persentase rendemen 55,06\%. Pada proses ekstraksi ini digunakan pelarut etanol. Etanol mudah diuapkan pada suhu $65{ }^{\circ} \mathrm{C}$ sehingga selain karena sifat kepolarannya juga karena memudahkan dalam memproleh ekstrak pekat.

Hasil rendemen yang paling tinggi pada sampel daging buah manggis menunjukkan bahwa lebih banyak senyawa polar yang terekstrak pada sampel tersebut dibandingkan sampel kulitnya. Hal ini sesuai dengan prinsip "like dissolve like", yaitu senyawa polar akan larut pada pelarut yang bersifat polar.

Hasil rendemen yang tinggi pada sampel daging buah manggis dapat berkaitan pula dengan karbohidrat (gula) yang tinggi pada sampel daging buah manggis dengan kadar mencapai $14 \%$ [6] dalam hal ini gula mudah larut dalam etanol yang bersifat polar. Persen rendemen diperoleh dengan membandingkan bobot ekstrak dengan bobot sampel lalu dikalikan $100 \%$.

Kemampuan pelarut etanol untuk melarutkan senyawa yang terkandung dalam ekstrak kulit manggis bisa di rujuk dari penelitian yang sudah ada yaitu penelitian tentang kelarutan kandungan Xanton, Antosianin dan total Fenolik dari tepung kulit manggis yang diekstrak dengan berbagai macam pelarut . [7]

Tabel 2. Kelarutan Zat Terkandung Dalam Kulit Manggis Yang Bisa Di Ekstrak Dengan Varian Pelarut Pada Proses Maserasi

\begin{tabular}{|c|c|c|c|c|}
\hline $\begin{array}{l}\text { Jenis } \\
\text { pelarut }\end{array}$ & $\begin{array}{l}\text { Kadar } \\
\text { Xanto } \\
\mathrm{n} \\
\text { (mg/g } \\
\text { tepun } \\
\mathrm{g} \\
\text { KBM) }\end{array}$ & $\begin{array}{l}\text { Kadar } \\
\text { Antosian } \\
\text { in (mg/g } \\
\text { Tepung } \\
\text { KBM) }\end{array}$ & $\begin{array}{l}\text { Kadar } \\
\text { Total } \\
\text { Fenoli } \\
\text { k } \\
\text { (mg/g } \\
\text { Tepun } \\
\text { g } \\
\text { KBM) }\end{array}$ & $\begin{array}{l}\text { Kapasitas } \\
\text { Antioksid } \\
\text { an } \\
(\%)\end{array}$ \\
\hline Air & 0,72 & 6,22 & 154,5 & 86,29 \\
\hline $\begin{array}{l}\text { Etanol } \\
70 \%\end{array}$ & 9,05 & 5,7 & $\begin{array}{l}136,9 \\
8\end{array}$ & 86,63 \\
\hline $\begin{array}{l}\text { Etanol } \\
96 \%\end{array}$ & 34,95 & 0,83 & 50,50 & 84,6 \\
\hline $\begin{array}{l}\text { Aseton } \\
72 \%\end{array}$ & 25,81 & 5,8 & $\begin{array}{l}118,9 \\
3\end{array}$ & 89,31 \\
\hline $\begin{array}{l}\text { Aseton } \\
90 \%\end{array}$ & 78,52 & 0,13 & 49,39 & 84,36 \\
\hline $\begin{array}{l}\text { Vitamin } \\
800 \text { ppm } \\
\text { (control } \\
\text { positif } \\
\text { antioksida } \\
\text { n) }\end{array}$ & & & & 79,26 \\
\hline
\end{tabular}

Dari tabel 2. Etanol teknis $(70 \%)$ dapat melarutkan total fenolik lebih banyak dari senyawa yang lain, sehingga bisa disimpulkan rendemen ekstrak kulit bagian dalam berasal dari sebagian besar total fenolik dan sebagian kecil Xanton dan Antosianin. Tabel 2. Ini pun menerangkan bahwa terdapat senyawa antioksidan polar dan nonpolar pada kulit manggis dan kapasitas antioksidan kulit manggis mampu bersaing dengan Vitamin $\mathrm{C}$ 800 ppm.

Hasil rendemen ekstrak kulit bagian luar dengan persentase 13,88 \% bisa dipastikan karena rendahnya kandungan senyawa polar pada ekstrak kulit bagian luar. Dari table 2 bisa dilihat bahwa Xanton dan antosianin lebih mudah dilarutkan dalam pelarut nonpolar aseton. 
Terkait dengan kandungan ekstrak kulit manggis terhadap efek sitotoksik bisa di rujuk pada penelitian aktivitas sitotoksik ekstrak air dan etanol kulit manggis pada sel kanker. Hasil MTT assay menunjukkan ekstrak etanol kulit manggis dan ekstrak air kulit manggis efektif terhadap sel kanker hepar HepG2 dengan IC50 berturut turut 96,1 dan $87,3 \mu \mathrm{g} / \mathrm{ml}$ dan berdasarkan karakterisasi KLT kedua ekstrak tersebut mengandung senyawa terpenoid dan flavonoid [8].

\section{UJI AKTIVITAS ANTIOKSIDAN SECARA PEREDAMAN RADIKAL BEBAS DPPH (2,2- DIPHENYL-1-PICRYLHYDRAZYL)}

Hasil uji aktivitas antioksidan sampel bagianbagian buah manggis secara peredaman radikal bebas DPPH (2,2-Diphenyl-1Pycrylhydrazyl) dapat dilihat pada Tabel 2.

Tabel 3. Data Hasil Uji Aktivitas Antioksidan secara Peredaman Radikal Bebas DPPH (2,2Diphenyl-1-Pycrylhydrazyl)

\begin{tabular}{|c|c|c|c|c|}
\hline No & Sampel & $\begin{array}{l}\text { Kadar } \\
(\mu \mathrm{g} / \mathrm{ml})\end{array}$ & $\begin{array}{l}\text { Persen } \\
\text { Inhibisi } \\
(\%)\end{array}$ & $\begin{array}{l}\text { IC50 } \\
(\mu \mathrm{g} / \mathrm{ml})\end{array}$ \\
\hline \multirow[t]{5}{*}{1} & \multirow{5}{*}{$\underset{\text { C }}{\text { Vitamin }}$} & 3,00 & 44,73 & \multirow[t]{5}{*}{1,41} \\
\hline & & 6,00 & 75,20 & \\
\hline & & 9,00 & 96,04 & \\
\hline & & 12,00 & 96,83 & \\
\hline & & 15,00 & 97,17 & \\
\hline \multirow[t]{5}{*}{2} & \multirow{5}{*}{$\begin{array}{l}\text { Daging } \\
\text { Buah }\end{array}$} & 5,00 & 11,44 & \multirow[t]{5}{*}{51,10} \\
\hline & & 10,00 & 17,67 & \\
\hline & & 25,00 & 32,62 & \\
\hline & & 50,00 & 54,93 & \\
\hline & & 100,00 & 83,80 & \\
\hline \multirow[t]{5}{*}{3} & \multirow{5}{*}{$\begin{array}{c}\text { Kulit } \\
\text { Bagian } \\
\text { Dalam }\end{array}$} & 5,00 & 21,97 & \multirow[t]{5}{*}{7,00} \\
\hline & & 10,00 & 42,92 & \\
\hline & & 25,00 & 94,79 & \\
\hline & & 50,00 & 95,13 & \\
\hline & & 100,00 & 95,47 & \\
\hline \multirow[t]{5}{*}{4} & \multirow{5}{*}{$\begin{array}{c}\text { Kulit } \\
\text { Bagian } \\
\text { Luar }\end{array}$} & 5,00 & 27,41 & \multirow[t]{5}{*}{1,95} \\
\hline & & 10,00 & 46,21 & \\
\hline & & 25,00 & 94,45 & \\
\hline & & 50,00 & 94,79 & \\
\hline & & 100,00 & 95,24 & \\
\hline
\end{tabular}

Aktivitas antioksidan dari bagian-bagian buah manggis yang diuji secara peredaman radikal bebas DPPH (2,2-Diphenyl-1-Pycrylhydrazy) dibandingkan dengan salah satu standar antioksidan yang sudah diketahui, yaitu vitamin C sebagai kontrol positif. Vitamin C digunakan sebagai kontrol positif karena merupakan salah satu senyawa antioksidan non enzimatis yang bekerja sebagai donor elektron saat bereaksi dengan radikal bebas. Hal ini dibuktikan dengan nilai $\mathrm{IC}_{50}$ yang diperoleh yaitu sebesar
$1,41 \mu \mathrm{g} / \mathrm{ml}$ yang menunjukkan bahwa pada konsentrasi tersebut vitamin $\mathrm{C}$ dapat meredam $50 \%$ aktivitas radikal bebas DPPH. Berdasarkan data hasil uji aktivitas antioksidan pada Tabel 2, dapat dilihat adanya korelasi antara konsentrasi dengan persen inhibisi (penghambatan). Semakin besar kadar sampel semakin besar pula penghambatannya.Pada sampel kulit buah manggis, baik bagian dalam maupun bagian luarnya, menghasilkan persen inhibisi lebih dari $94 \%$ mulai konsentrasi 25 $\mu \mathrm{g} / \mathrm{ml}$. Hal ini menunjukkan bahwa hampir seluruh radikal bebas DPPH yang ditambahkan pada sampel kulit bagian dalamdan kulit bagian luar buah manggis telah bereaksi dengan antioksidan dalam sampel dan telah terstabilkan.

Sesuai data yang diperoleh nilai $\mathrm{IC}_{50}$ untuk sampel kulit bagian dalam, kulit bagian luar da daging buah manggis berturut-turut sebesar $(7,00 ; 1,95$ dan 51,10$) \mu \mathrm{g} / \mathrm{ml}$ sehingga dapat dikatakan bahwa ketiga sampel bagian buah manggis memiliki aktivitas antioksidan. Semakin kecil nilai $\mathrm{IC}_{50}$ suatu bahan alam, maka semakin besar aktivitas antioksidannya. Aktivitas antioksidan tertinggi berdasarkan data tersebut diperoleh dari sampel kulit bagian luar buah manggis.Data tersebut menunjukkan bahwa potensi kulit bagian luar buah manggis sebagai antioksidan sangat kuat bahkan hampir mendekati aktivitas antioksidan standar vitamin C. Selain itu sampel kulit bagian dalam juga dikategorikan memiliki aktivitas antioksidan yang sangat kuat pula menghasilkan nilai $\mathrm{IC}_{50}<50 \mu \mathrm{g} / \mathrm{ml}$.

Aktivitas antioksidan pada manggis diakibatkan terkandungnya senyawa xanthone di dalamnya, terutama derivatnya yaitu $\gamma$ mangostin yang memiliki aktivitas antioksidan terbesar [9]. Berdasarkan data dapat disimpulkan bahwa ketiga sampel memiliki potensi sebagai antioksidan.

\section{UJI TOKSISITAS SECARA BRINE SHRIMP LETHALITY TEST (BSLT)}

Data hasil pengujian toksisitas secara BSLT dapat dilihat pada Tabel 3.

Tabel 4. Data Hasil Pengujian Toksisitas secara Brine Shrimp Lethality Test (BSLT) 


\begin{tabular}{|c|c|c|c|c|c|c|c|c|c|}
\hline \multirow[t]{2}{*}{\begin{tabular}{l|l}
$N$ \\
$\mathrm{O}$
\end{tabular}} & \multirow{2}{*}{$\begin{array}{l}\text { Konse } \\
\text { ntrasi } \\
\text { Ekstr } \\
\text { ak } \\
(\mu \mathrm{g} / \\
\mathrm{ml})\end{array}$} & \multicolumn{3}{|c|}{$\begin{array}{l}\text { Jumlah } \\
\text { Larva } \\
\text { Hidup }\end{array}$} & \multicolumn{4}{|c|}{$\begin{array}{l}\text { Jumlah Larva } \\
\text { Mati }\end{array}$} & \multirow{2}{*}{$\begin{array}{l}\mathrm{LC}_{50} \\
(\mu \mathrm{g} \\
/ \mathrm{ml} \\
)\end{array}$} \\
\hline & & 1 & 2 & 3 & 1 & 2 & 3 & $\begin{array}{l}\text { To } \\
\text { tal }\end{array}$ & \\
\hline 1 & $\begin{array}{l}\text { Blank } \\
\text { o }\end{array}$ & $\begin{array}{l}1 \\
0\end{array}$ & $\begin{array}{l}1 \\
0\end{array}$ & $\begin{array}{l}1 \\
0\end{array}$ & 0 & 0 & 0 & 0 & - \\
\hline 2 & $\begin{array}{l}\text { EKBD } \\
1000\end{array}$ & 0 & 0 & 0 & $\begin{array}{l}1 \\
0 \\
\end{array}$ & $\begin{array}{l}1 \\
0\end{array}$ & $\begin{array}{l}1 \\
0 \\
\end{array}$ & 30 & $\begin{array}{l}6,2 \\
9\end{array}$ \\
\hline 3 & $\begin{array}{l}\text { EKBD } \\
100 \\
\end{array}$ & 0 & 0 & 0 & $\begin{array}{l}1 \\
0 \\
\end{array}$ & $\begin{array}{l}1 \\
0\end{array}$ & $\begin{array}{l}1 \\
0 \\
\end{array}$ & 30 & \\
\hline 4 & $\begin{array}{l}\text { EKBD } \\
10 \\
\end{array}$ & 0 & 0 & 1 & $\begin{array}{l}1 \\
0\end{array}$ & $\begin{array}{l}1 \\
0\end{array}$ & 9 & 29 & \\
\hline 5 & $\begin{array}{l}\text { EKBL } \\
1000\end{array}$ & 0 & 0 & 0 & $\begin{array}{l}1 \\
0\end{array}$ & $\begin{array}{l}1 \\
0\end{array}$ & $\begin{array}{l}1 \\
0\end{array}$ & 30 & $\begin{array}{l}9,1 \\
7\end{array}$ \\
\hline 6 & $\begin{array}{l}\text { EKBL } \\
100 \\
\end{array}$ & 0 & 0 & 0 & $\begin{array}{l}1 \\
0 \\
\end{array}$ & $\begin{array}{l}1 \\
0 \\
\end{array}$ & $\begin{array}{l}1 \\
0 \\
\end{array}$ & 30 & \\
\hline 7 & $\begin{array}{l}\text { EKBL } \\
10 \\
\end{array}$ & 2 & 5 & 5 & 8 & 5 & 5 & 18 & \\
\hline 8 & $\begin{array}{l}\text { EDB } \\
1000\end{array}$ & 5 & 6 & 7 & 5 & 4 & 3 & 12 & $\begin{array}{l}115 \\
8,4\end{array}$ \\
\hline 9 & $\begin{array}{l}\text { EDB } \\
100\end{array}$ & 9 & 8 & 9 & 1 & 2 & 1 & 4 & 7 \\
\hline $\begin{array}{l}1 \\
0\end{array}$ & $\begin{array}{l}\text { EDB } \\
10\end{array}$ & $\begin{array}{l}1 \\
0\end{array}$ & 9 & $\begin{array}{l}1 \\
0\end{array}$ & 0 & 1 & 0 & 1 & \\
\hline
\end{tabular}

Keterangan :

EKBD = Ekstrak Kulit Bagian Dalam

EKBL = Ekstrak Kulit Bagian Luar

$\mathrm{EDB}=$ Ekstrak Daging Buah

Berdasarkan pengujian yang telah dilakukan diperoleh nilai $\mathrm{LC}_{50}$ untuk ektsrak kulit bagian dalam, kulit bagian luar dan daging buah manggis berturut-turut sebesar $(6,29 ; 9,17$ dan 1158,47) $\mu \mathrm{g} / \mathrm{ml}$. Berdasarkan hasil tersebut dapat dikatakan bahwa ekstrak kulit buah manggis baik bagian dalam maupun bagian luarnya memiliki potensi toksik akut terhadap Artemia salina L, karena menghasilkan nilai $\mathrm{LC}_{50} \leq 1000 \mu \mathrm{g} / \mathrm{ml}$ sedangkan untuk ekstrak daging buah manggis tidak memiliki potensi toksik karena menghasilkan nilai $\mathrm{LC}_{50}>$ $1000 \mu \mathrm{g} / \mathrm{ml}$. Berdasarkan pengujian dapat dikatakan bahwa ekstrak kulit bagian dalambuah manggis memiliki potensi toksik akut tertinggi terhadap larva udang Artemia salina $L$.

Pengujian toksisitas ini di lakukan 24 jam dengan menghitung jumlah larva udang yang mati pada masing masing konsentrasi. Data hasil pengujian ini diolah dengan metode probit analisis secara komputerisasi menggunakan SPSS 14 for windows untuk menentukan nilai $\mathrm{LC}_{50}$ (Lethal Concentration 50), yaitu dosis tunggal suatu zat yang akan membunuh $50 \%$ hewan uji, semakin kecil nilai $\mathrm{LC}_{50}$ suatu zat maka daya toksiknya terhadap hewan uji semakin tinggi pula. Uji Toksisitas secara BSLT ini merupakan uji toksisitas akut kareana efek toksik dari suatu senyawa ditentukan dalam waktu singkat, yaitu rentang waktu selama 24 jam setelah pemberian sampel uji.

Berdasarkan hasil pengujian aktivitas antioksidan dan toksisitas yang telah dilakukan. Sampel memiliki daya toksik yang tinggi ternyata memiliki potensi antioksidan yang tinggi pula, yaitu sampel kulit bagian dalam dan luar. Hal ini disebabkan bahwa senyawa yang berkhasiat antioksidan memiliki aktivitas farmakologi pula, berdasarkan literatur penelitian yang sudah ada.

Senyawa xanthone yang paling tinggi dalam kulit manggis adalah $\alpha$-mangostin, senyawa ini mampu menekan pembentukan karsinogen dalam kolon dan bersifat antioksidan.[7]Titik leleh senyawa Xantone cukup tingi yaitu $173-176{ }^{\circ} \mathrm{C}$ sehingga tidak rusak ketika di refluks pada suhu $85{ }^{\circ} \mathrm{C}$. Antosianin adalah kelompok pigmen yang berwarna merah sampai biru. Senyawa antosianin memiliki kemampuan sebagai antioksidan dan memiliki peranan yang cukup penting dalam pencegahan penyakit neuronal, penyakit kanker dan diabetes.[7] Oleh karena memiliki sejumlah khasiat maka bisa dikatakan senyawa ini menyumbangkan keaktifan terhadap benih udang Artemia Salina L. [7] Senyawa Fenolik mempunyai nilai kapasitas antioksidan yang tinggi sehingga memiliki keaktifan yang cukup untuk uji sitotoksik. [7] Berbeda dengan sampel daging buah manggis yang tidak memiliki daya toksik, aktivitas antioksidannya pun lebih rendah. Senyawa bioaktif yang bersifat toksik berdasarkan metode BSLT disebabkan karena terkandungnya antosianin dan xanton yang memiliki kemampuan aktivitas farmakologi [7].

Terdapat penelitian yang menunjukkan ekstrak etanol kulit manggis (Garcinia mangostana L) memiliki aktivitas sitotoksik terhadap sel kanker kolon WiDr dengan IC $\mathrm{C}_{50}$ sebesar $24 \hat{A} \mu \mathrm{g} / \mathrm{ml}$. Deteksi apoptosis dengan double staining menggunakan akridin oranye dan etidium bromide menunjukkan bahwa ekstrak kulit manggis (Garcinia mangostana L) tunggal menginduksi apoptosis sel WiDr ditandai dengan adanya fragmentasi sel.[12]

Terdapat pula penelitian yang menunjukkan kemampuan antibakteri ekstrak etanol kulit manggis (Garcinia mangostana L) terhadap bakteri Porphyromonas Gingivalis. Pengujian aktivitas antibakteri menunjukkan bahwa ekstrak etanol kulit manggis memiliki $\mathrm{khm}$ dan $\mathrm{kbm}$ terhadap bakteri Porphyromonas Gingivalis masing masing pada konsentrasi $25 \%$ dan $50 \%$ dan dapat disimpulkan bahwa ekstrak etanol kulit manggis 
memiliki efek bakterisidal terhadap bakteri Porphyromonas Gingivalis.[13]

\section{SIMPULAN DAN SARAN}

\section{SIMPULAN}

1. Berdasarkan pengujian aktivitas antioksidan yang telah dilakukan disimpulkan ketiga sampel memiliki potensi aktivitas antioksidan dengan nilai $I_{50}$ berturut-turut, yaitu 1,95 $\mu \mathrm{g} / \mathrm{ml}$ (ekstrak kulit bagian luar), 7,00 $\mu \mathrm{g} / \mathrm{ml}$ (ekstrak kulit bagian dalam ) dan 51,10 $\mu \mathrm{g} / \mathrm{ml}$ (ekstrak daging buah manggis)

2. Berdasarkan hasil uji toksisitas diperoleh nilai LC 50 sampel berturut-turut sebesar $6,29 \mu \mathrm{g} / \mathrm{ml}$ (ekstrak kulit bagian dalam), 9,17 $\mu \mathrm{g} / \mathrm{ml}$ (ekstrak kulit bagian luar) dan 1158,47 $\mu \mathrm{g} / \mathrm{ml}$ (ekstrak daging buah manggis) sehingga dapat disimpulkan ekstrak yang berpotensi akut hanya ekstrak kulit bagian dalam dan ektrak kulit bagian luar sedangkan ekstrak daging buah manggis tidak berpotensi toksik.

\section{SARAN}

Perlu dilakukan pengujian lebih lanjut untuk mengetahui struktur senyawa aktif yang berpotensi memiliki aktivitas antioksidan dan bersifat toksik sehingga dapat lebih mudah dalam mengembangkannya sebagai bahan obat.

\section{DAFTAR PUSTAKA}

[1]. Chaverry J.P et al. 2008. Medical Properties of Mangosteen (Garcinia mangostana). Elsevier. 46:3227-3239. http://www.elsevier.com/locate/food chemtox diakses pada tanggal 11 april 2019 pkl 21:04 WIB

[2]. Gunawan, D \& S. Mulyani.2004. IImu Obat Alam (Farmakologis). Jilid 1. Penebar Swadaya. Bogor.

[3]. Chin, Y.W \& A.D Khinghorn. 2008.Structural characterization biological effects, and synthetic studies on xanthones from mangosteen (Garcinia mangostana), a popular botanical dietary supplement. MiniRev.Org.Chem. 5(4): 355-364. http://www.ncbi.nlm.nih.gov/pmc/art icles/PMC3090081/
[4]. Meyer, B.N et.al. 1982. Brine Shrimp : a convenient general bioassay for active plant constituents. Planta Medica. $\quad$ 45: 31-34. http://www.ncbi.nlm.nih.gov/pubme d/17396775

[5]. Horwitz,W.(Ed).1990. Official Methods of Analysis of The Association of Official Analytical Chemist, $15^{\text {th }}$ Edition, Association of Official Analytical Chemist, Washington, D.C.

[6]. Daniel,M. 2006. Medical Plants : Chemistry and Properties. Science Publisher, Toronto.

[7]. Widayanti,SM et al.2009.Kapasitas dan Kadar Antioksidan Ekstrak Tepung Kulit Buah Manggis (Garcinia mangostana L.) pada Berbagai Pelarut dengan Metode Maserasi. Jurnal Pascapanen.6 (2): 61-68

[8]. Haryanti, S et al.2017. Aktivitas Sitotoksik Ekstrak Air dan Etanol Kulit Manggis ( Garcinia mangostana.L) pada beberapa Model Sel Kanker. Balai Besar Penelitian dan pengembangan Tanaman Obat dan Obat Tradisional, Badan Penelitian dan pengembangan Kesehatan, Kementerian Kesehatan RI. Volume 10, no 1 Agustus 2017.

[9]. Jung, H.A et al. 2006. Antioxidant xanthones from pericarp of Garcinia mangostana ( mangosteen). J.Agric.Food.Chem 54 : 2077-2082. http://www.ncbi.nlm.nih.gov/pubme d/16536578

[10]. Harmita \& M.Radji. 2006. Buku Ajar Analisis Hayati. Ed ke-3. Penerbit Buku Kedokteran EGC, Jakarta.

[11]. Winarsih,H. 2007. Antioksidan Alami \& Radikal Bebas Potensi Dan Aplikasinya Dalam Kesehatan. Kanisius, Yogyakarta

[12]. Meiyanto,E\&Rohmah, A.L. 2013.Peningkatan Efek Sitotoksik dan 
Induksi Apoptosis Doxorubicin oleh Ekstrak Etanolik Kulit Buah Manggis (Garcinia mangostana L) pada Sel Kanker Kolon WiDr In Vitro. Skripsi UGM.

Http://etd.repository.ugm.ac.id/penel itian/detail/65289

[13]. Sriyono,R.A.N \&Andriani,I.2013. Daya Antibakteri Ekstrak Etanol Kulit Manggis (Garcinia mangostana L) terhadap Bakteri Porphyromonas Gingivalis. IDJ .Vol 2 No 2 Tahun 2013. Program Studi Pendidikan Dokter Gigi FKIK Universitas Muhammadiyah Yogyakarta. 